\title{
ANALIZA POŠTANSKOG TRŽIŠTA U REPUBLICI HRVATSKOJ
}

\author{
Dora Naletina \\ Dr. sc., docent, Sveučilište u Zagrebu, Ekonomski fakultet, Trg J. F. Kennedyja 6, 10000 Zagreb, Hrvatska; \\ e-mail: dora.naletina@efzg.hr
}

Ante Vuletić

Dr. sc., docent, Sveučilište u Zagrebu, Ekonomski fakultet, Trg J. F. Kennedyja 6, 10000 Zagreb, Hrvatska; e-mail:avuletic2@net.efzg.hr

\section{Luka Meštrović}

Mag. oec., Geoprojekt d. d., Sukoišanska 43, 21000 Split, Hrvatska; e-mail: luka.mestrovic@yahoo.com

\section{SAŽETAK}

Tržište poštanskih usluga, kako u Republici Hrvatskoj, tako i u većini ostalih svjetskih država, prolazi kroz velike promjene kao posljedica sve češćeg korištenja elektroničke komunikacije te supstitucije poštanskih usluga. Napredak tehnologije utječe i na promjene ponašanja korisnika, kao i na njihova očekivanja u vezi s kvalitetom i brzinom usluge. U Republici Hrvatskoj djeluju gotovo svi na svjetskoj razini prepoznati pružatelji usluga paketne distribucije, a njihov je cilj da u što kraćem vremenu i uz što višu razinu kvalitete usluge isporuče pošiljku primatelju. Cilj ovog rada je analizirati stanje na poštanskom tržištu u Republici Hrvatskoj. Posljednjih godina sve je izraženiji utjecaj supstitucije poštanskih usluga elektroničkim, što se ogleda u padu obujma pismovnih pošiljaka. S druge strane raste broj distribuiranih paketa kod većine poštanskih operatora u zemljama članicama i to zahvaljujući rastu elektroničke trgovine. Navedeni trendovi nisu zaobišli ni hrvatsko poštansko tržište na kojem su se također korisnici okrenuli češćoj online kupovini, što je potenciralo trend rasta dostavljenih paketa. Temeljem provedene analize zaključuje se kako unatoč uspostavi potpune liberalizacije hrvatskog poštanskog tržišta i dalje dominira nacionalni operator, Hrvatska pošta d. d., no on pod utjecajem promjena na tržištu poslovanje više ne temelji isključivo na tradicionalnim poslovima, već širi svoju ponudu dodatnim uslugama.

Ključne riječi: liberalizacija, paketna distribucija, poštanske usluge, Republika Hrvatska

\section{UVOD}

Tržište poštanskih usluga ima važnu ulogu u gospodarskom i društvenom razvoju mnogih država. Većina država je ovo tržište gradila putem nacionalnih poštanskih operatora ili nacionalnih 
poštanskih uprava. Postupne promjene na ovom tržištu započele su 1994. godine inicijativom za uspostavu jedinstvenog tržišsta poštanskih usluga u Europskoj uniji (Kollara, 2017:10). Poštanske usluge pojavile su se kako bi zadovoljile komunikacijske potrebe čovjeka, a njihovo zadovoljavanje temelji se na mrežnoj organizaciji koja omogućava prijevoz ili slanje poruka ili paketa na daljinu (Lăzărescu, 2017). Paketna distribucija je djelatnost koja se odnosi na distribuciju roba u paketnom obliku. Važnost paketne distribucije raste, posebice zahvaljujući kupovini internetom na koju se odlučuje sve veći broj korisnika. Poštanske usluge čine pismovne, paketne i poštansko-uputničke usluge (Enciklopedija.hr, N/A). Proces paketne distribucije te broj sudionika u njemu ponajprije ovisi o tome koji model distribucije određeno poduzeće primjenjuje, a u literaturi se ističu ambulantna i centralna distribucija. Usluge paketne distribucije bitne su za zadovoljenje potreba brojnih industrija. Javni i privatni korisnici oslanjali su se i oslanjaju se na poštanske usluge za razmjenu informacija, dokumenata, paketa ili pisama (Hillebrand et al., 2016:3). Sudionici u poslovanju međunarodne paketne distribucije su svi subjekti koji sudjeluju u procesu međunarodne paketne distribucije od trenutka davanja naloga za slanje do isporuke pošiljke te razlikuju direktne sudionike, poduzeća za paketnu distribuciju, transportne organizacije koje sudjeluju u procesu distribucije i državne institucije vezane uz distribuciju i transport (Bendeković i Batarelo, 2009:81). Svi sudionici u procesu paketne distribucije trebali bi međusobno koordinirati svoje aktivnosti jer upravo o njima ovisi koliko će na kraju biti uspješan cijeli proces.

Tržište poštanskih usluga vrlo je slično telekomunikacijskom tržištu te su ključni igrači nacionalni poštanski operatori i privatni operatori. Osnovni cilj poduzeća koje se bavi paketnom distribucijom je u što kraćem vremenu te uz minimalne troškove dostaviti paket i na taj način osigurati zadovoljstvo svih sudionika u procesu (Kollara, 2017:36). Brzina i točnost isporuke postaje sve važnija korisnicima te može biti temelj za uspostavu konkurentske prednosti poduzećima koje se bave tom djelatnošću (Seitz, Razzouk i Williams, 2008). Dwianto i Purnamasari (2018) ističu kako kod korisnika sve dominantniji utjecaj na zadovoljstvo uslugama dostavljača paketa ima spremnost poduzeća da im pruži informacije o brzini te alternativnim mogućnostima glede dostave pošiljke.

Za potrebe ostvarivanja cilja rada provedeno je opsežno sekundarno istraživanje koje je uključivalo analizu dostupne znanstvene i stručne domaće i međunarodne literature i analizu regulatornog okvira. Problem istraživanja opisan je metodom deskripcije, dok su prikupljeni podaci analizirani metodama analize, sinteze te kompilacije.

\section{TRENDOVI NA POŠTANSKOM TRŽIŠTU}

Poštanska poduzeća te poduzeća koja se bave distribucijom paketa suočavaju se sa sve zahtjevnijim okruženjem. Poduzetnici se moraju nositi s ubrzanim promjenama koje se javljaju kao posljedica eksponencijalnog napretka tehnologije, koje utječu na promjene ponašanja korisnika, kao i na njihova očekivanja u vezi s kvalitetom i brzinom usluge (Accenture Consulting, 2017). Već je desetljećima poštanska industrija nudila poštanske usluge pritom uživajući monopolsku poziciju preko nacionalnih poštanskih operatora. Zahvaljujući pritiscima Europske unije za uspostavu liberaliziranog tržišta poštanskih usluga, uspostavljeni su uvjeti za ulazak novih poduzeća, ali su i usklađene poštanske usluge unutar zemalja članica. Ostatak Europe također odlikuje provedba djelomične ili potpune liberalizacije na tržištu poštanskih usluga. Liberalizacija je potaknuta 
iz više razloga: neučinkovitosti nacionalnih poštanskih operatora, upitnih regulativa kojima se štitio monopolski položaj nacionalnih operatora, pritiska konkurencije te promjena u ponašanju korisnika. Poštanski operatori su se, kako bi opstali i spriječili daljnji pad prihoda, morali prilagoditi ubrzanim promjenama u okruženju te su počeli razvijati digitalne poštanske usluge, odnosno usluge koje podržava odgovarajuća internetska infrastruktura i kombinacija aktivnosti hardvera i softvera (Kollara, 2017).

Kada korisnici obavljaju kupovinu u fizičkim prodavaonicama tada jednostavno i sami odnose doma robu nakon što su ju platili. U slučaju e-kupovine situacija je bitno drugačija, s obzirom na to da se prodavač i kupac ne nalaze na istom mjestu u trenutku realizacije kupnje. Stoga se javlja potreba za dostavljačem koji će prevesti robu od prodavača kupcu, što predstavlja priliku za pružatelje usluga distribucije paketa, jer se količina proizvoda kupljenih online rapidno povećava (Jaag i Maegli, 2014). Komunikacijska uloga poštanskih usluga smanjuje se zbog razvoja drugih tržišta usko vezanih uz poštansko tržište (Hillebrand et al., 2016:3-4). Navedeno podrazumijeva brojne izazove za tradicionalni poštanski lanac vrijednosti. Kako bi se prilagodili tim novim uvjetima u okruženju, poštanski operatori moraju redefinirati komunikacijske usluge pošte te raditi na razvoju kombiniranih usluga s dodanom vrijednošću od digitalizacije. Četiri su dimenzije ključne ako poduzeće na tržištu distribucije paketa želi uspješno poslovati (Accenture Consulting, 2017): 1. Obraniti osnovnu djelatnost; 2. Pobolǰsavati uslugu distribucije paketa; 3 . Selektivno preusmjeravanje i 4 . U što većoj mjeri težiti uspostavi digitalizacije poslovanja. Nekada su procesi na poštanskom tržištu bili statični jer se radilo o prikupljanju, sortiranju, transportu te konačno isporuci paketa primatelju. Danas kupci žele imati i opciju odgode dostave kao i preusmjeravanja dostave na drugu adresu. Za daljnju integraciju različitih opcija isporuke ključna je suradnja pružatelja usluge dostave te e-prodavača (Hillebrand et al., 2016:4).

U 2017. godini nastavljeni su trendovi prijašnjih godina te se ponovo bilježi pad obujma pismovnih pošiljaka dok kod većine poštanskih operatora u zemljama članicama raste broj distribuiranih paketa. S ciljem prilagodbe navedenim promjenama na tržištu, poštanski operatori ulažu sredstva u poboljšanje infrastrukturnih uvjeta za pružanje usluga, optimiziraju procese rada te pojednostavljuju ponudu i izlaze ususret svojim korisnicima (Hrvatska pošta, 2017:6). Sve veći broj poštanskih operatora nudi mogućnost dostave $u$ večernjim satima, kao i dostave subotom. Ekspresne i kurirske službe predstavljaju poseban segment na tržištu poštanskih usluga, pružajući dodanu vrijednost dostavljanjem pošiljke od vrata do vrata. $S$ time da se sve više uslugama distribucije paketa bave i logističari (van der Lijn et al., 2005:16). Trenutno se na tržištu poštanskih usluga nude 3 grupe usluga: pismovne pošiljke, paketne pošiljke te ekspresne i kurirske usluge. Pismovne pošiljke podrazumijevaju pošiljke težine manje od 2 kilograma, dok se paketne pošiljke odnose na pošiljke težine od 2 do 20 kilograma. Ekspresne i kurirske usluge odnose na usluge dodane vrijednosti kod kojih se u pravilu radi o dostavi "od vrata do vrata".

Poštanski operatori posljednjih godina u svrhu bolje prilagodbe promjenama u okruženju implementiraju strategiju za kontrolu troškova na nekoliko načina: uspostavom fleksibilnije organizacije, smanjivanjem troškova mreže kako bi se uskladili s manjim volumenom posla; ulaganjem u tehnologiju za poboljšanje operativne učinkovitosti te pomicanjem prema skupnim pismovnim paketima (Kollara, 2017:51). 


\section{POŠTANSKO TRŽIŠTE U REPUBLICI HRVATSKOJ}

\section{1 Regulatorni okvir poštanskog tržišta u Republici Hrvatskoj}

Nacionalno zakonodavstvo kojim se regulira poštansko tržište u Republici Hrvatskoj u potpunosti je usklađeno s direktivama Europske unije i liberalizirano, čime su uspostavljeni jedinstveni uvjeti i načini funkcioniranja za sve sudionike (Ministarstvo pomorstva, prometa i infrastrukture, 2014:2). Zakonodavni okvir kojim se regulira tržište poštanskih usluga u Republici Hrvatskoj definiran je zakonima te određenim podzakonskim propisima (Tablica 1).

Tablica 1. Zakonodavni okvir kojim se regulira tržište poštanskih usluga u Republici Hrvatskoj

\begin{tabular}{|c|c|c|}
\hline & PROPISI & Nadležnost \\
\hline \multirow[t]{2}{*}{ I. } & Zakon o poštanskim uslugama (NN, 144/12, 153/13, 78/15) & MMPI \\
\hline & PODZAKONSKI PROPISI & \\
\hline 1. & Pravilnik o obavljanju univerzalne usluge (NN, 41/13) & HAKOM \\
\hline 2. & Pravilnik o poštanskim markama (NN, 91/13, 153/13, 78/15, 61/16) & MMPI \\
\hline 3. & $\begin{array}{l}\text { Pravilnik o plaćanju naknada za obavljanje poslova Hrvatske regulatorne } \\
\text { agencije za mrežne djelatnosti (NN, 33/17) }\end{array}$ & HАKOM \\
\hline 4. & $\begin{array}{l}\text { Pravilnik o načinu rada Povjerenstava za zaštitu prava korisnika usluga (NN, } \\
52 / 15 \text { ) }\end{array}$ & НАКОМ \\
\hline 5. & $\begin{array}{l}\text { Pravilnik o službenoj iskaznici i znački poštanskog inspektora i o očevidniku } \\
\text { poštanskog inspektora (NN, 42/13) }\end{array}$ & MMPI \\
\hline II. & $\begin{array}{l}\text { ZAKONI O POTVRĐIVANJU MEĐUNARODNIH UGOVORA KOJI SE } \\
\text { ODNOSE NA PODRUČJE POŠTANSKIH USLUGA }\end{array}$ & \\
\hline 1. & $\begin{array}{l}\text { Zakon o potvrđivanju Sporazuma o poštanskim uslugama plaćanja (NN, } \\
\text { međunarodni ugovori, 3/16) }\end{array}$ & MMPI \\
\hline 2. & $\begin{array}{l}\text { Zakon o potvrđivanju Svjetske poštanske konvencije sa Završnim protokolom } \\
\text { (NN, međunarodni ugovori, 1/11) }\end{array}$ & MMPI \\
\hline 3. & $\begin{array}{l}\text { Zakon o potvrđivanju Općih pravila Svjetske poštanske unije (NN, } \\
\text { međunarodni ugovori, } 3 / 16 \text { ) }\end{array}$ & MMPI \\
\hline 4. & $\begin{array}{l}\text { Zakon o potvrđivanju Petoga dodatnog protokola uz Ustav Svjetske } \\
\text { poštanske unije, Šestoga dodatnog protokola uz Ustav Svjetske poštanske } \\
\text { unije i Sedmoga dodatnog protokola uz Ustav Svjetske poštanske unije (NN, } \\
\text { međunarodni ugovori, } 5 / 08 \text { ) }\end{array}$ & MMPI \\
\hline 5. & $\begin{array}{l}\text { Ustav Svjetske poštanske unije sa Završnim protokolom (NN, međunarodni } \\
\text { ugovori, 4/07) }\end{array}$ & MMPI \\
\hline
\end{tabular}




\begin{tabular}{|l|l|c|}
\hline 6. & $\begin{array}{l}\text { Zakon o potvrđivanju Prvog dodatnog protokola uz Opća pravila Svjetske } \\
\text { poštanske unije (NN, međunarodni ugovori, 1/11) }\end{array}$ & MMPI \\
\hline 7. & $\begin{array}{l}\text { Zakon o potvrđivanju Osmog dodatnog protokola uz Ustav Svjetske } \\
\text { poštanske unije (NN, međunarodni ugovori, 1/11) }\end{array}$ & $\mathrm{MMPI}$ \\
\hline III. & $\begin{array}{l}\text { Zakon o razdvajanju Hrvatske pošte i telekomunikacija na Hrvatsku poštu i } \\
\text { Hrvatske telekomunikacije (NN, 101/98) }\end{array}$ & $\mathrm{MMPI}$ \\
\hline
\end{tabular}

Napomena: MMPI - Ministarstvo pomorstva, prometa i infrastrukture; HAKOM - Hrvatska agencija za poštu i elektroničke komunikacije

Izvor: izrada autora

Temeljni propis kojim se regulira tržište poštanskih usluga je Zakon o poštanskim uslugama (NN 144/12, 153/13, 78/15) čije se odredbe primjenjuju na sve davatelje poštanskih usluga te na usluge u međunarodnom poštanskom prometu, ako aktima Svjetske poštanske unije nije drukčije određeno (NN, 144/12). U sklopu istoga definiran je i pojam univerzalne poštanske usluge. Univerzalnost usluge bitna je zbog liberalizacijskog procesa odnosno otvaranja ovog tržišta sudionicima iz drugih zemalja članica. Ista podrazumijeva skup poštanskih usluga određene kakvoće koje su dostupne po pristupačnoj cijeni svim korisnicima poštanskih usluga na cijelom području Republike Hrvatske, neovisno o njihovoj zemljopisnoj lokaciji (NN, 144/12). Na snazi je pet podzakonskih propisa vezanih za Zakon o poštanskim uslugama. Zakonom o razdvajanju Hrvatske pošte i telekomunikacija na Hrvatsku poštu i Hrvatske telekomunikacije uređeno je razdvajanje navedenih javnih poduzeća na dva dionička društva: 'Hrvatske pošte' zadužene za poslovno područje pošte te 'Hrvatske telekomunikacije' za područje telekomunikacija (NN, 101/98).

Hrvatska regulatorna agencija za mrežne djelatnosti koja je sljednik Hrvatske agencije za telekomunikacije (HAT), među ostalim je zadužena za regulaciju tržišta poštanskih usluga. HAKOM je nacionalno regulatorno tijelo za obavljanje regulatornih poslova u području poštanskih usluga te se zadaće HAKOM-a u području poštanske djelatnosti odnose na (NN, 78/15):

1. javne ovlasti koje je Republika Hrvatska Zakonom prenijela na HAKOM

2. javnu objavu davatelja poštanskih usluga te

3. ostale zadaće koje se odnose na smjernice za učinkovit i djelotvoran rad.

Proces stvaranja unutarnjeg tržišta za poštanske usluge, kao i odgovarajuće usklađivanje poštanskog zakonodavstva zemalja članica, svakako je najvažniji pokretač promjena u nacionalnim poštanskim regulativama zemalja članica, ali i poticaj razvoju konkurencije na nacionalnim poštanskim tržištima (van der Lijn et al., 2005:44). Liberalizacija predstavlja skup sistemskih mjera koje poduzimaju kako regulatori tako i sudionici na tržištu, a s ciljem unifikacije tržišta te olakšanja prometa uz povećanje kvalitete i dostupnosti usluga (Miletić, 2012:186). S obzirom na to da se posljednjih godina sve više razvijaju tehnološki sofisticirani načini komuniciranja, potreba za tradicionalnim poštanskim uslugama postaje upitna. Liberalizacija je nužna kako bi se otvaranjem tržišta različitim poslovnim subjektima omogućilo unapređenje kvalitete, ali i razvoj novih usluga (Tomša, 2010:490). Proces liberalizacije tržišta poštanskih usluga u Europskoj uniji započeo je 11. lipnja 1992. godine kada 
je Europska komisija predstavila Zelenu knjigu o razvoju jedinstvenog tržišta poštanskih usluga (EUR-Lex, 15. 12. 1997.). Cilj Zelene knjige bio je osigurati ukidanje nacionalnih monopola te potaknuti otvaranje natječaja za nove pružatelje usluga kako bi se uspostavile njihove niže cijene i veća dostupnost (Žujo, 22. 7. 2013.).

Europsko pravo poštanskih usluga sastoji se od 3 Direktive kojima se regulira razvoj poštanskog tržišta u Europskoj uniji, a to su (European Commission, N/A):

1. Direktiva 97/67/EC od 15. prosinca 1997. godine

2. Direktiva 2002/93 od 10. lipnja 2002. godine

3. Direktiva 2008/6/EC od 20. veljače 2008. godine.

U Republici Hrvatskoj 31. 12. 2012. smatra se datumom potpune liberalizacije tržišta poštanskih usluga, što podrazumijeva primjenu tržišnog natjecanja koje reflektira uspostavu mehanizma za stvaranje jednakih uvjeta svim sudionicima na tržištu. Dok se o procesu liberalizacije tržišta poštanskih usluga u Europskoj uniji govorilo još 1988. godine u okviru Bijele knjige o poštanskim uslugama, u Hrvatskoj se počeci ovog procesa vežu uz 1994. godinu, odnosno donošenje Zakona o pošti u okviru kojeg se u 24. članku navodi kako usluge prijenosa paketa mogu obavljati i druge pravne i fizičke osobe u uvjetima slobodnog tržišta. Formalizacija procesa liberalizacije u Republici Hrvatskoj započela je usvajanjem (Ministarstvo pomorstva, prometa i infrastrukture, 2014:3):

1. Zakona o pošti 2003. godine kada je ukinut monopol Hrvatskoj pošti d. d. za pismovne pošiljke iznad 100 grama, ali i

2. Osnivanjem Vijeća za poštanske usluge - neovisnog nacionalnog regulatornog tijela za poštanske usluge.

U Hrvatskoj nacionalno regulatorno tijelo na poštanskom tržištu predstavlja Hrvatska regulatorna agencija za mrežne djelatnosti. Većina zemalja članica Europske unije provela je liberalizaciju poštanskog tržišta, stoga iste karakterizira velik broj konkurenata na tržištu (Kollara, 2017:45). U analizi procesa liberalizacije tržišta poštanskih usluga u Republici Hrvatskoj bitno je istaknuti kako je donošenjem Zakona o poštanskim uslugama u 2009. godini osigurano usklađivanje nacionalnog zakonodavstva s Drugom poštanskom direktivom dok je donošenjem Zakona o poštanskim uslugama u 2012. te izmjenama istog u 2013. godini osigurana implementacija Treće poštanske direktive (Ministarstvo pomorstva, prometa i infrastrukture, 2014:3).

\section{2 Pružatelji poštanskih usluga u Republici Hrvatskoj}

Na tržištu poštanskih usluga u Republici Hrvatskoj trenutno djeluje 22 davatelja poštanskih usluga od kojih jedino HP-Hrvatska pošta d. d. ima pravo na davanje univerzalne usluge. Zamjenska poštanska usluga podrazumijeva: prijam, usmjeravanje, prijenos i uručenje pismovnih pošiljaka mase do $2 \mathrm{~kg}$, paketa mase do $10 \mathrm{~kg}$ i preporučenih pošiljaka i pošiljaka s označenom vrijednosti. Za pružanje zamjenskih usluga uz HP-Hrvatska pošta $d$. $d$. registrirana su još 4 poduzeća: Lider Express d. o. o. (Zagreb), Lider Express d. o. o. (Žrnovnica), Pošta Express j. d. o. o. (Vinkovci) i Tisak 
d. d. (Zagreb). Samo HP-Hrvatska pošta d. d. i Tisak d. d. pružaju zamjenske poštanske usluge u unutarnjem i međunarodnom prometu, dok ih ostala tri pružatelja pružaju samo u unutarnjem prometu. Za pružanje ostalih poštanskih usluga registrirano je 21 poduzeće, od čega ih glavnina (14) ima sjedište u Zagrebu. Bitno je naglasiti da su neka od tih poduzeća registrirana i za obavljanje zamjenskih poštanskih usluga (Hrvatska regulatorna agencija za mrežne djelatnosti, 27. 3. 2018.). Pozitivna kretanja na poštanskom tržištu u Republici Hrvatskoj nastavljena su i u 2017. godini. Porast prihoda ponajprije je uzrokovan rastom broja prenesenih paketa (vidi Tablica 2 i Grafikon 2), ali i sve većim brojem usluga s dodanom vrijednosti (Lider, 4. 9. 2017.).

Tablica 2. Poštanske i kurirske usluge u Republici Hrvatskoj od 2007. do 2016.

\begin{tabular}{|c|c|c|c|c|c|c|c|}
\hline & \multirow{2}{*}{ Broj } & \multicolumn{2}{|c|}{ Pismovne i ostale pošiljke (mil.) } & \multicolumn{3}{|c|}{ Paketne pošiljke (000) } \\
\cline { 5 - 8 } & pristupnih & Unutarnji & $\begin{array}{c}\text { Međunarodni } \\
\text { mpomet }\end{array}$ & UKUPNO & $\begin{array}{c}\text { Unutarnji } \\
\text { promet }\end{array}$ & $\begin{array}{c}\text { Međunarodni } \\
\text { promet }\end{array}$ & UKUPNO \\
\hline 2007. & 1192 & 362 & 37 & 399 & 6241 & 220 & 6461 \\
\hline 2008. & 1185 & 353 & 38 & 391 & 7383 & 245 & 7628 \\
\hline 2009. & 1191 & 351 & 23 & 374 & 7439 & 245 & 7684 \\
\hline 2010. & 1185 & 324 & 21 & 345 & 7426 & 263 & 7689 \\
\hline 2011. & 1255 & 309 & 19 & 328 & 7778 & 281 & 8059 \\
\hline 2012. & 1185 & 299 & 20 & 319 & 8651 & 278 & 8929 \\
\hline 2013. & 2088 & 282 & 22 & 303 & 9778 & 620 & 10398 \\
\hline 2014. & 2235 & 305 & 24 & 328 & 12360 & 1259 & 13619 \\
\hline 2015. & 2050 & 294 & 24 & 318 & 13033 & 1715 & 14749 \\
\hline 2016. & 2117 & 291 & 22 & 313 & 14260 & 2239 & 16499 \\
\hline
\end{tabular}

Izvor: Državni zavod za statistiku (2017). Statistički ljetopis Republike Hrvatske. Zagreb: Državni zavod za statistiku, str. 36.

U tablici 2 može se uočiti gotovo udvostručenje broja pristupnih mjesta u 2013. godini u odnosu na 2012. godinu. Do 2012. godine oni su obuhvaćali broj poštanskih ureda i drugih mjesta za preuzimanje i dostavu pošiljaka, dok se od 2013. godine taj podatak odnosi na broj svih fizičkih objekata davatelja poštanskih usluga u kojima korisnici mogu dobivati poštanske usluge. Također raste udio međunarodnog prometa paketnih pošiljaka koji je u 2016. godini iznosio 2239 tisuća komada odnosno 13,37 \% od ukupnog prometa paketnim pošiljkama. lako je taj udio malen, izuzetno je velik uzme li se u obzir da je udio paketnih pošiljki u međunarodnom prometu u 2007. godini iznosio svega $3,4 \%$.

Analizom tržišnih udjela davatelja poštanskih usluga uočava se dominacija Hrvatske pošte $d$. $d$. s udjelom od 82,2 \%. Naravno, treba uzeti u obzir da je Hrvatska pošta d. d. jedino poduzeće koje je ovlašteno pružati univerzalnu poštansku uslugu u Republici Hrvatskoj, a udio univerzalne poštanske usluge u svim poštanskim uslugama u 2017. godini iznosio je visokih 59,00 \%. 
Grafikon 1. Tržišni udjeli davatelja poštanskih usluga prema broju ostvarenih usluga

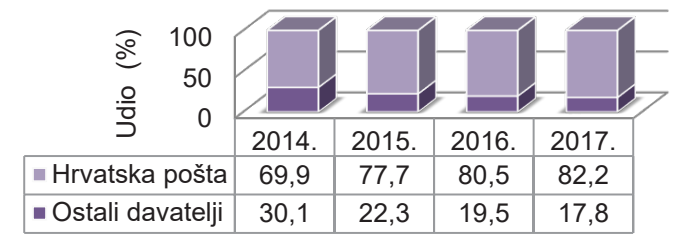

Izvor: izradili autori prema podacima Hrvatske regulatorne agencije za mrežne djelatnosti (N/A). Tržišni pokazatelji. Poštanske usluge (ukupne usluge).

Na grafikonu 1 uočava se trend rasta udjela Hrvatske pošte d. d., što implicira kako se ulaganje u razvoj novih proizvoda i skretanje fokusa s isključivo tradicionalnih usluga isplatilo. Hrvatska pošta d. d. posljednjih se godina usmjerila na razvoj paketnog poslovanja s obzirom na to da ono predstavlja velik potencijal zbog značajnog volumena na rastućem tržištu (Hrvatska pošta, 2017:9).

Grafikon 2. Broj poštanskih usluga prema vrstama pošiljaka od 2014. do 2017. godine

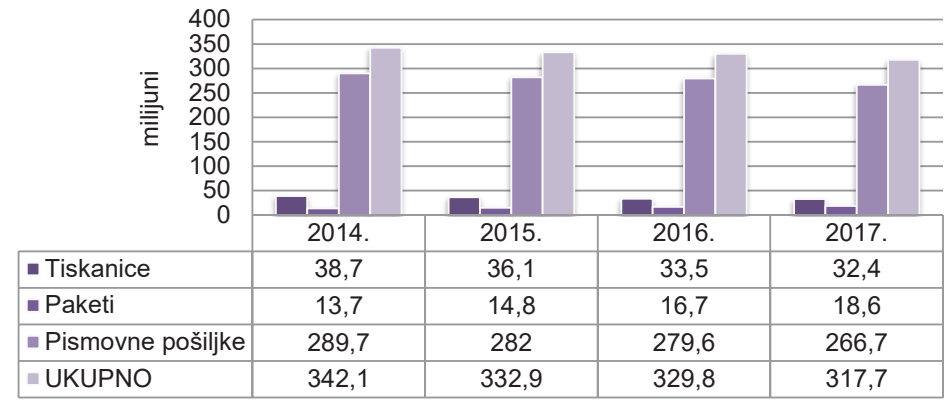

Izvor: izradili autori prema podacima Hrvatske regulatorne agencije za mrežne djelatnosti (N/A). Tržišni pokazatelji. Poštanske usluge (ukupne usluge).

U 2017. godini pruženo je ukupno 317.7 milijuna poštanskih usluga, što je za 3,7 \% manje u odnosu na 2016. godinu. U promatranom razdoblju uočava se trend rasta ukupnog broja dostavljenih paketa (vidi Grafikon 2) te je on u 2017. godini bio veći za 35,77 \% negoli u 2014. godini. Važno je spomenuti udruživanje Hrvatske pošte d. d. i njemačkog logističkog poduzeća DHL-a koji su 23. kolovoza 2017. godine u Bonnu potpisali ugovor o suradnji u dostavi paketa. Time je Hrvatska pošta d. d. potvrdila kako posjeduje adekvatnu tehnologiju te da pruža uslugu iznimne kvalitete. Strategijom razvoja tržišta poštanskih usluga u Republici Hrvatskoj do 2020. godine sljedeći segmenti održivog razvoja poštanskog sektora identificirani su kao ključni (Ministarstvo pomorstva, prometa i infrastrukture, 2014):

1. Učinkovitije korištenje prijevoznih sredstava, edukacija djelatnika o ekološki prihvatljivoj vožnji i ulaganje u ekološki prihvatljivija prijevozna sredstva.

2. Poboljšanje energetske učinkovitosti jedinica poštanske mreže.

3. Ekološko zbrinjavanje otpada kroz mjere razdvajanja otpada, upotrebu materijala koji su u potpunosti razgradivi te razvoj aplikacija za unapređenje ekološkog aspekta poslovanja. 


\section{3 Modeli poslovnih strategija na poštanskom tržištu}

Poštansko tržište posljednjih godina prošlo je velike promjene zbog utjecaja tehnološkog napretka te promjena u regulatornom okviru uslijed liberalizacijskog procesa. Sam proces distribucije pošiljke znatno se pojednostavnio. Dok se prije dvadesetak godina nalog za distribuciju pošiljke davao telefonski, danas se većina naloga daje internetom (Jaag, 2015:34). U Europi se posljednjih deset godina kupovne navike jako brzo mijenjaju te raste udio korisnika koji kupovinu obavljaju online, stoga su pružatelji usluga paketne distribucije primorani mijenjati svoje modele poslovanja (Morganti et al., 2014). Za očekivati je da će u budućnosti pošiljatelj direktno kontaktirati vozača za prikupljanje pošiljke, a isto će biti posljedica ubrzanog razvoja mobilnih tehnologija te njihovog doprinosa unapređenju razvoja komunikacije (Bendeković i Batarelo, 2009:85).

Paketna distribucija vrlo je složena industrija čiji je primarni cilj djelotvorno koristiti skupe resurse i zadovoljiti vremensku komponentu. Prilikom traženja odgovarajućeg poslovnog modela nužno je spojiti dva ključna i povezana potproblema: skupljanje i usmjeravanje pošiljki te balansiranje s dostupnom opremom (Cohn et al., 2007). Strategija paketne distribucije podrazumijeva izvršni plan aktivnosti kojima se specificira što pojedinac ili poduzeće mora obaviti kada mu se dodijeli određeni zadatak (Ulwick, 1999:4). Na tržištu paketne distribucije postoje brojni poslovni modeli, a isti jednako variraju unutar samih država, koliko i, primjerice, između zemalja članica Europske unije. Zajedničko svim tim poslovnim modelima je da se bitno razlikuju od poslovnog modela nacionalnih poštanskih operatora. Strategije nacionalnih poštanskih operatora pod utjecajem su raznih čimbenika, a najvažniji su sljedeći (van der Lijn et al., 2005:18):

1. Tradicionalna osnovica prihoda sve se više smanjuje. Porast konkurencije utječe na smanjenje volumena pošiljki kojima rukuju nacionalni poštanski operatori.

2. Financijski rezultati nacionalnih poštanskih operatora pokazuju poprilično nezadovoljavajuću stopu povrata na prodaju.

3. Regulatorni okvir Europske unije zabranjuje kontinuiranu državnu potporu nacionalnim operatorima.

4. Pritisci konkurencije zahtijevaju kontinuirani razvoj novih proizvoda i procesa.

Navedeno stvara pritiske na postojeće modele nacionalnih poštanskih operatora koji moraju poboljšati učinkovitost u pružanju poštanskih usluga i proširiti postojeću ponudu ako žele opstati na tržištu, a ne oslanjajući se pritom na subvencije države. Strategije nacionalnih poštanskih operatora uvelike se razlikuju od države do države. Primjerice, nacionalni poštanski operator u Luksemburgu je još u 2009. godini svega $20 \%$ prihoda ostvarivao od tradicionalnih aktivnosti, dok je druge prihode generirao zahvaljujući dodatnim financijskim i logističkim uslugama iz svoje ponude. S druge strane, nacionalni poštanski operator na Cipru je 97,5 \% svojih prihoda ostvario od tradicionalnih aktivnosti. Udio prihoda od tradicionalnih aktivnosti u ukupnim prihodima je pokazatelj koji generira na koji se model poslovanja određeno poduzeće odlučilo (Okholm i sur., 2010:33). Nacionalni poštanski operatori diljem Europe moraju osigurati dodatne prihode pružanjem novih usluga i smanjiti ovisnost o isključivo prihodima od pružanja univerzalne usluge (Kujačić, Šarac, Jovanović, 2009:12). 


\section{Naletina, A. Vuletić, L. Meštrović: Analiza poštanskog tržišta u Republici Hrvatskoj Zbornik Veleučilišta u Rijeci, Vol. 7 (2019), No. 1, pp. 301-315}

Nacionalni poštanski operatori prilikom širenja svojeg poslovanja primjenjuju sljedeće tri strategije (Okholm et al., 2010:34):

1. Horizontalnu ekspanziju koja podrazumijeva akviziciju poduzeća na istoj razini u opskrbnom lancu na kojoj se nalazi i stjecatelj.

2. Vertikalnu konsolidaciju koja podrazumijeva uzvodnu akviziciju.

3. Diversifikaciju. Dolazi do stjecanja poduzeća koje se ne nalazi u istom lancu vrijednosti.

Bendeković i Batarelo (2009:86) modele poslovnih strategija paketne distribucije razlikuju u odnosu na način na koji korisnik usluga paketne distribucije uspostavlja kontakt i komunikaciju s pružateljem usluga distribucije paketa, a razlikuju tri osnovna modela:

1. Pozivni model koji se temelji na čistom komercijalnom otvorenom tržišnom principu gdje se na jednoj strani javlja korisnik koji traži uslugu distribucije paketa dok je na drugoj strani poduzeće koje nudi uslugu distribucije paketa. Idealan je u situacijama kada korisnik nema stalnu potrebu za ovakvom vrstom usluge.

2. Ugovorni model.Korisnik ima izraženiju potrebu za uslugama poduzeća za paketnu distribuciju, stoga se javlja potreba za sklapanjem ugovora.

3. Kombinirani model. Osnovna odlika ovog modela je univerzalnost koja mu omogućava da zadovolji sve zahtjeve za distribucijom paketa. Najodgovorniji je model poslovanja od analiziranih modela jer poduzeće mora ispunjavati zahtjeve korisnika svojih usluga postavljene na temelju ugovora, ali i zahtjeve korisnika koji nemaju sklopljen ugovor.

U procesu distribucije paketa zapravo je primatelj paketa glavni kupac te prilikom odabira poslovnog modela upravo treba voditi računa o tome (Wällstedt, 1. 7. 2018.). Posljednjih godina tržište poštanskih usluga pod znatnim je pritiscima napretka informacijske tehnologije, što je u velikoj mjeri utjecalo na promjene navika korisnika, stoga se javila potreba uvođenja novih, kako poštanskih, tako usluga koje nisu poštanske. Navedeno zahtijeva i prilagodbu poslovnog modela novim strategijama (Ministarstvo pomorstva, prometa i infrastrukture, 2014:66). U novom poslovnom modelu nije uključen samo razvoj novih proizvoda i usluga, već i inovacije u kompletnom postojećem poslovnom procesu kao i načinu organizacije poslovanja. Situacija na tržištu pošiljaka ubrzano se mijenja, a prije svega posljednjih godina rapidno opada potražnja za distribucijom pisama (engl. letter distribution) koja je prethodno bila najvažniji dio poslovanja poduzeća na ovom tržištu. S druge strane, potražnja za distribucijom paketa (engl. parcel delivery) brzo raste (Wällstedt, 1. 7. 2018.). Navedeno implicira potrebu za traženjem novih poslovnih modela. Upravo povećana potreba online trgovaca za distribucijom pošiljaka predstavlja priliku za poduzeća koja pružaju usluge distribucije paketa. Navedeno zahtijeva i izmjenu poslovnog modela, a ključno je usvojiti digitalne tehnologije kako bi se brzo moglo odgovoriti na zahtjeve s tržišta. Za usvajanje tog poslovnog modela potrebno je proći kroz proces digitalne transformacije. No, poduzeće nikako ne smije zanemariti svoje tradicionalne aktivnosti, koje svakako treba osuvremeniti i poboljšati operativnu učinkovitost (Saggia, 2. 3. 2018.). 
Na shemi 1 uočava se kako pristup prilagođavanja poslovnog modela na tržištu poštanskih usluga novim tržišnim potrebama varira od inovativnog načina optimizacije postojećeg poslovnog modela, pa sve do kreiranja sasvim novih poštanskih usluga te do diversifikacije portfelja ulaskom u druge gospodarske svrhe (Ministarstvo pomorstva, prometa i infrastrukture, 2014:66). Inovacije temeljene na tehnološkom napretku ne redefiniraju samo proizvode, već utječu i na promjenu očekivanja kupaca. Korisnici su manje zabrinuti oko toga otkuda dolazi njihov paket, a najviše brinu oko cijene i brzine dostave (Accenture Consulting, 2017). Pružatelji poštanskih usluga već su se 2009. godine počeli suočavati s negativnim stopama rasta koje su dijelom bile posljedica utjecaja financijske krize, a većim dijelom posljedica sve češće upotrebe interneta od strane korisnika, kao i nedostatka adekvatnih inovacija.

Shema 1. Utjecaj prilagođavanja poslovnog modela na tržištu poštanskih usluga novim tržišnim potrebama

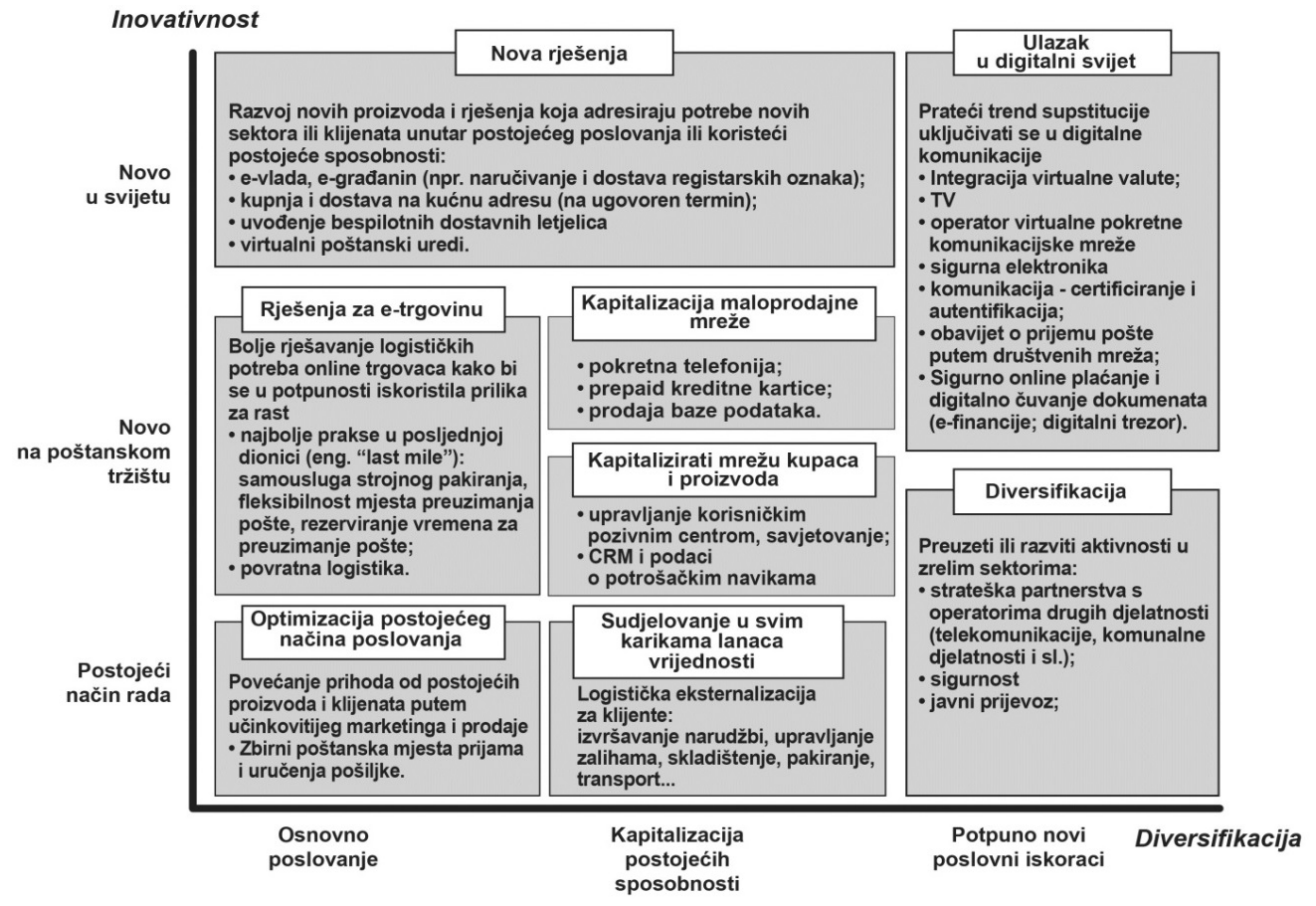

Izvor: izradili autori prema Ministarstvu pomorstva, prometa i infrastrukture (2014). Strategija razvoja tržišta poštanskih usluga u Republici Hrvatskoj do 2020. godine, str. 67.

Ranije su davatelji poštanskih usluga svoje poslovanje temeljili prvenstveno na fizičkoj platformi za dostavu pismovnih pošiljaka i paketa, dok se posljednjih godina nameće uspostava drugačije platforme kao posljedica korištenja interneta te razvoja širokopojasnih pristupnih tehnologija (Ministarstvo pomorstva, prometa i infrastrukture, 2014). Poštanska i poduzeća za distribuciju paketa počinju shvaćati prednosti digitalizacije i da su ta ulaganja temelj za ostvarivanje uspješnog poslovanja u budućnosti (Accenture Consulting, 2017). 


\section{ZAKLJUČAK}

Industrija poštanskih usluga koja uključuje paketnu distribuciju ima važnu ulogu u gospodarskom i društvenom razvoju mnogih država. Osnovni cilj poduzeća koje se bavi paketnom distribucijom je da u što kraćem vremenu te uz minimalne troškove dostavi paket te da na taj način osigura da svi sudionici u procesu budu zadovoljni. Pošiljatelj i primatelj bit će zadovoljniji što je dostava brža, dok će se ostali sudionici u ovom distribucijskom procesu zadovoljiti s naknadom za obavljene usluge. Poštanska poduzeća te poduzeća koja se bave distribucijom paketa suočavaju se sa sve zahtjevnijim okruženjem, a poduzetnici se moraju nositi s ubrzanim promjenama koje se javljaju kao posljedica eksponencijalnog napretka tehnologije. Napredak tehnologije utječe i na promjene ponašanja korisnika, kao i na njihova očekivanja u vezi s kvalitetom i brzinom usluge. Stoga se posljednjih godina sve više koriste elektroničke usluge, što smanjuje obujam pismovnih pošiljaka te utječe na rast broja distribuiranih paketa. Temeljem provedene analize uočeno je kako hrvatsko poštansko tržište nisu zaobišli navedeni trendovi. S ciljem prilagodbe navedenim promjenama na tržištu, poštanski operatori ulažu sredstva u poboljšanje infrastrukturnih uvjeta za pružanje usluga, optimiziraju procese rada te pojednostavljuju ponudu i izlaze u susret svojim korisnicima. $\mathrm{Na}$ tržištu poštanskih usluga u Republici Hrvatskoj trenutno djeluje 22 davatelja poštanskih usluga, ali valja naglasiti kako Hrvatska pošta i dalje ima dominantnu ulogu. Hrvatski nacionalni poštanski operator prepoznao je potrebu prilagodbe svoje strategije promjenama na tržištu, stoga širi svoju ponudu i drugim, a ne samo tradicionalnim uslugama. Preporuka je da se provede primarno istraživanje ispitivanja zadovoljstva korisnika kvalitetom usluga na poduzeću tržišta poštanskih usluga u Republici Hrvatskoj kako bi se mogla donijeti cjelokupna ocjena o stanju na tržištu poštanskih usluga. Buduća istraživanja mogla bi se usmjeriti na analizu strategija nacionalnog poštanskog operatora te strategija privatnih poštanskih operatora, kako bi se mogle definirati karakteristike optimalnog modela poštanskog operatora.

\section{LITERATURA}

Accenture Consulting (2017). The new delivery reality. Achieving High Performance in the Post and Parcel Industry 2016, https://www.accenture.com/t20170320T061145Z_w__/us-en/_acnmedia/PDF-42/Accenture-The-New-deliveryReality-HP-Post-and-Parcel-research-2016.pdf\#zoom $=50$ (26. 6. 2018.)

Bendeković, J., Batarelo, T. (2009) “Modeli poslovnih strategija međunarodne paketne distribucije", Poslovna izvrsnost, 3(2), str. 79-98

Cohn, A. et al. (2007) "Integration of the load-matching and routing problem with equipment balancing for small package carriers", Transportation Science, 41(2), str. 238-252. https://doi.org/10.1287/trsc.1060.0174

Državni zavod za statistiku Republike Hrvatske (2017) Statistički ljetopis Republike Hrvatske 2017, god. 49, Zagreb: Državni zavod za statistiku Republike Hrvatske

Dwianto, A. S., Purnamasari, P. (2018) "Analysis the influence of service quality on customer satisfaction of domestic postal parcels at Kantor Pos Banjarmasin", U: Proceedings International Seminar On Accounting for Society, International Seminar on Accounting for Society, Pamulang: Faculty of Economy, 1(1).

Enciklopedija.hr (N/A) Pošta, http://www.enciklopedija.hr/natuknica.aspx?id=49722\# (12. 7. 2018.) 
EUR-Lex (15.12.1997.) Direktiva 97/67/EZ Europskog parlamenta i Vijeća o zajedničkim pravilima za razvoj unutarnjeg tržišta poštanskih usluga u Zajednici i poboljšanje kvalitete usluga. Svezak 9, https://eur-lex.europa.eu/legal-content/ HR/TXT/?uri=celex\%3A31997L0067 (14. 6. 2018.)

European Commission (N/A) Postal services Overview, http://ec.europa.eu/competition/sectors/postal_services/ overview_en.html (20.7.2018.)

Hillebrand, A. et al. (2016) Technology and change in postal services - impacts on consumers. Bad Honnef: WIK Consult and ITA Consulting

Hrvatska pošta (2017)Godišnjeizvješćeza 2016.godinu.Zagreb:Hrvatska pošta d. d., http://www.zse.hr/UserDocsImages/ financ/HP-fin2016-1Y-REV-N-HR.pdf(11. 9. 2018.)

Hrvatska regulatorna agencija za mrežne djelatnosti (27. 3. 2018.) Popis davatelja poštanskih usluga, https://www.hakom. hr/default.aspx?id=586 (4. 9. 2018.)

Hrvatska regulatorna agencija za mrežne djelatnosti (N/A) Tržišni pokazatelji. Poštanske usluge (Ukupne usluge), https:// www.hakom.hr/UserDocsImages/2018/e_trziste/GOD\%20HRV\%202017-Ukupne\%20usluge.pdf (4. 9. 2018.)

Jaag, C. (2015) “Postal sector development between digitalization and regulation”, U: Finger, M., Jaag, C. (Ur.) Chapter 3 in The Routledge Companion to Network Industries, London: Routledge, str. 25-36

Jaag, C., Maegli, M. (2015) “Market regulations and USO in the revised Swiss Postal Act: Provisions and authorities", U: Chapter 23 in Topics in Regulatory Economics and Policy, Cham: Springer, str. 301-311. https://doi.org/10.1007/9783-319-12874-0_23

Kollara, N. H. (2017) Digital transformation, business models and the postal industry, doktorska disertacija, Ecole polytechnique fédérale de Lausanne

Kujačić, M., Šarac, D., Jovanović, B. (2009) “Model održivosti univerzalnog poštanskog servisa”, U: XXVII Simpozijum o novim tehnologijama u poštanskom i telekomunikacionom saobraćaju - PosTel 2009, Beograd, str. 3-13.

Lăzărescu, C. (2017) "The Postal Market - a New Economic Challenge in the Context of Globalization", Journal of Humanistic and Social Studies, br. 1, str. 187-196

Lider (04.09.2017.) “Hrvatska pošta ispunila stroge kriterije, ušla u partnerstvo s DHL-om”, https://lider.media/aktualno/ tvrtke-i-trzista/poslovna-scena/hrvatska-posta-ispunila-stroge-kriterije-usla-u-partnerstvo-s-dhl-om/ (10. 9. 2018.)

Miletić, Z. (2012) “Trendovi europskog tržǐ̌ta”, Ekonomska misao i praksa, Vol. 21, br. 1, str. 179-201.

Ministarstvo pomorstva, prometa i infrastrukture (2014) Strategija razvoja tržišta poštanskih usluga u Republici Hrvatskoj do 2020. godine, http://www.mppi.hr/UserDocsImages/Strategija_postanske_usluge_RH_v54-listopad. pdf (14. 6. 2018.)

Morganti, E. et al. (2014) "The impact of e-commerce on final deliveries: alternative parcel delivery services in France and Germany", Transportation Research Procedia, Vol. 4, str. 178-190. https://doi.org/10.1016/j.trpro.2014.11.014

Narodne novine (1998) Zakon o razdvajanju Hrvatske pošte i telekomunikacija na Hrvatsku poštu i Hrvatske telekomunikacije, Zagreb: Narodne novine d. d., br. 101

Narodne novine (2007) Ustav Svjetske poštanske unije sa Završnim protokolom, Zagreb: Narodne novine d. d., međunarodni ugovori, br. 4

Narodne novine (2008) Zakon o potvrđivanju Petoga dodatnog protokola uz Ustav Svjetske poštanske unije, Šestoga dodatnog protokola uz Ustav Svjetske poštanske unije i Sedmoga dodatnog protokola uz Ustav Svjetske poštanske unije, Zagreb: Narodne novine d. d., međunarodni ugovori, br. 1

Narodne novine (2011) Zakon o potvrđivanju Osmog dodatnog protokola uz Ustav Svjetske poštanske unije, Zagreb: Narodne novine d. d., međunarodni ugovori, br. 1

Narodne novine (2011) Zakon o potvrđivanju Prvog dodatnog protokola uz Opća pravila Svjetske poštanske unije, Zagreb: Narodne novine d. d., međunarodni ugovori, br. 1 
Narodne novine (2011) Zakon o potvrđivanju Svjetske poštanske konvencije sa Završnim protokolom, Zagreb: Narodne novine d. d., međunarodni ugovori, br. 1

Narodne novine (2013) Pravilnik o obavljanju univerzalne usluge, Zagreb: Narodne novine d. d., br. 41

Narodne novine (2013) Pravilnik o službenoj iskaznici i znački poštanskog inspektora i o očevidniku poštanskog inspektora, Zagreb: Narodne novine d. d., br. 42

Narodne novine (2013) Zakon o izmjenama Zakona o poštanskim uslugama, Zagreb: Narodne novine d. d., br. 153

Narodne novine (2015) Pravilnik o načinu rada Povjerenstva za zaštitu prava korisnika usluga, Zagreb: Narodne novine d. d., br. 52

Narodne novine (2015) Strategija razvoja tržišta poštanskih usluga u Republici Hrvatskoj do 2020. godine, Zagreb: Narodne novine d.d, br. 125

Narodne novine (2015) Zakon o izmjenama i dopunama Zakona o poštanskim uslugama, Zagreb: Narodne novine d. d., br. 78

Narodne novine (2016) Zakon o potvrđivanju Općih pravila Svjetske poštanske unije, Zagreb: Narodne novine d. d., međunarodni ugovori, br. 3

Narodne novine (2016) Zakon o potvrđivanju Sporazuma o poštanskim uslugama plaćanja, Zagreb: Narodne novine d. d., međunarodni ugovori, br. 3

Narodne novine (2017) Pravilnik o plaćanju naknada za obavljanje poslova Hrvatske regulatorne agencije za mrežne djelatnosti, Zagreb: Narodne novine d. d., br. 33

Okholm, H. B. et al. (2010) Main developments in the postal services (2008-2010), Copenhagen: Copenhagen Economics

Pravilnik o poštanskim markama, NN 153/13, 78/15, 61/16, Zagreb: Narodne novine d. d.

Saggia, G. (02.03.2018.) "The Future of Postal Service: Digital Transformation Driving new Business Models. SAP africa News Center, https://news.sap.com/africa/2018/03/the-future-of-postal-services-digital-transformation-drivingnew-business-models/ (26. 6. 2018.)

Seitz, V., Razzouk, N., Williams, S. L. (2008) "Small Package Transportation Companies: An Exploratory Analysis. Review of Economic and Business Studies", br. 2, str. 77-92

Tomša, H. (2010) “Liberalizacija poštanske službe”, Hrvatska i komparativna javna uprava, 10(2), str. 489-514.

Ulwick, A. W. (1999) Business strategy formulation: theory, process, and the intellectual revolution, Westport: Quorum Books

Van der Lijn, N. et al. (2005) Development of competition in the European postal sector, Rotterdam: ECORYS Research and Consulting

Wällstedt, M. (1. 7. 2018.) "Innovate with New Business Models in the Postal and Parcel Industry. PocketMobial. A trimble company", https://precom.nu/innovate-with-new-business-models-in-the-postal-and-parcel-industry/ (16. 8. 2018.)

Zakon o poštanskim uslugama, NN 144/12, 153/13, 78/15, Zagreb: Narodne novine d. d.

Žujo, M. (22. 7. 2013.) “Liberalizacija tržišta pošta u Europskoj uniji dala različite rezultate”, Poslovni dnevnik, http://www. poslovni.hr/svijet-i-regija/liberalizacija-trzista-posta-u-eu-dala-razlicite-rezultate-247946 (16. 6. 2018.) 


\section{ANALYSIS OF POSTAL MARKET IN THE REPUBLIC OF CROATIA}

\section{Dora Naletina}

PhD, Assistant Professor, University of Zagreb, Faculty of Economics \& Business, Trg J. F. Kennedyja 6, 10000 Zagreb, Croatia; e-mail:dora.naletina@efzg.hr

\section{Ante Vuletić}

PhD, Assistant Professor, University of Zagreb, Faculty of Economics \& Business, Trg J. F. Kennedyja 6, 10000 Zagreb, Croatia; e-mail: avuletic2@net.efzg.hr

\section{Luka Meštrović}

MA in Economics, Geoprojekt d.d., Sukoišanska 43, 21000 Split, Croatia;

e-mail: luka.mestrovic@yahoo.com

\section{SUMMARY}

In Croatia, as in almost all other countries of the world, the postal services market has been going through big changes that are the consequence of the growing use of electronic communication and the fact of the postal services being substituted by it. Technological advancement also influences the changes in the behaviour of users and their expectations regarding the quality and the speed of the service provided. Almost all of the world-renown package distribution service providers whose goal is to deliver the parcels as quickly and as efficiently as possible operate in the Republic of Croatia. The goal of this paper is to analyse the state of affairs on the postal market in the Republic of Croatia. Over the last years, postal services have been increasingly substituted with electronic services, as evidenced by fewer letters being sent by the post. On the other hand, the number of the distributed parcels has been growing, due to the development of e-commerce. These trends are also present on the Croatian postal market, where buyers have become increasingly oriented towards online shopping, resulting in more packages being delivered. Based on the conducted analysis, the conclusions are drawn that, despite of the fact that the Croatian postal market has been completely liberalized, the market is still dominated by the national operator Hrvatska pošta d.d. However, under the influence of the market changes, the operator expands its offer by providing additional services and not just relying on the traditional business activities.

Key words: liberalisation, parcel consignment, postal service, Republic of Croatia 